\title{
BOOKING TRAVEL THROUGH THE AIRBNB PLATFORM DURING THE COVID 19 PANDEMIC
}

\author{
Elena Ştiubea \\ Doctoral School of Economic Sciences, Faculty of Economic Sciences, Oradea, Romania \\ elenastiubea@yahoo.com
}

\begin{abstract}
The collaborative economy, even if it has moulded well in the tourism market and has developed surprisingly, has been a controversial field from the very beginning, especially as it does not take place within a very well regulated legislative framework. The outbreak of the COVID 19 pandemic severely destabilized all industries, but among the most vulnerable to it was tourism. Not much is known yet about the impact of COVID 19 on traditional sectors, let alone studies or analyses of how the pandemic has affected non-traditional peer-to-peer accommodation. This article attempts a brief analysis of how people have booked or canceled their trips through the Airbnb platform since the beginning of the pandemic. The results show that the sharpest decline was recorded in April 2020 when the number of bookings fell by $72 \%$, compared to the same period in 2019. In the summer months, when most people plan their vacation, the bookings were not numerous, but they kept a certain stability. Compared to June-September 2019, bookings in 2020, during the same period, decreased by $20 \%$. The pandemic has hit this sector hard, especially as all pre-pandemic forecasts showed significant increases in peer-to-peer accommodation between 2020 and 2025 and therefore increases in overall revenue as a result of bookings. This study shows that peer-to-peer accommodation is just as vulnerable to such a pandemic as traditional accommodation. Providers need to rethink their offer in order to reduce financial losses and at the same time protect their employees and provide them with job stability. It can be seen that the cancellations and alterations of the services booked through Airbnb increased exponentially after the outbreak of the COVID 19 pandemic because people could no longer travel from one place to another and even if certain journeys were allowed, people were afraid or felt uncomfortable taking trips.
\end{abstract}

Keywords: Airbnb; COVID 19; collaborative economy.

JEL classification: 035

\section{Theoretical framework}

There are a number of studies that show that the collaborative economy has destabilized the field of tourism, through its originality, thus becoming an important element in the tourism industry. The collaborative economy offers tourists the opportunity to 'have resources and [...] organize among themselves or mingle with the closely related residential consumer species and act like producers' (Gretzel, Werthner, Koo, \& Lamsfus, 2015). Among the many consequences that the collaborative economy has had on tourism has been the possibility of accommodating tourists in high-demand destinations where accommodation at certain times of the year was almost impossible. Thus, thanks to the services offered by the collaborative economy, the accommodation offer has increased and tourists can find a place to stay. At the same time, choosing such an accommodation increases the trust in personto-person (P2P) accommodation services (Bardhi and Eckhardt, 2012). The collaborative economy has the potential to create new jobs, thus reducing unemployment in the area, by involving local communities in promoting tourist destinations and providing tourist services. The first area of tourism to be disrupted by the emergence of the collaborative economy was hospitality, where traditional accommodation is in direct competition with P2P 
accommodation. Due to this situation many traditional accommodations had to adjust their offer and reorient themselves (Juul, 2015). The expansion of collaborative consumption in tourism has led many platforms, such as Airbnb, to offer tours and experiences to tourists once they arrive at their destination, via websites and mobile apps. An important role in the implementation and development of collaborative tourism in a destination is played by locals willing to get involved and tour guides, who can turn an ordinary holiday into an authentic, original and memorable tourist experience (Badulescu and Badulescu, 2016). The services offered by the collaborative economy are directly linked to the availability and use of internetbased technologies and collaborative platforms.

The latter are important both from the perspective of those managing the platforms and from the perspective of their users (Caldieraro et al, 2018). Thus, the proper functioning of the platforms requires an adequate IT 'infrastructure'. A well-developed infrastructure facilitates access to these services, makes them more popular and leads to increased use of collaborative services. Thus, it can be said that the intention to use collaborative services depends not only on financial and social motivation, but on an interaction of several factors, such as the spread of the Internet, the cultural influence of the place or the demographic factor, which determine people's participation in such services. At the same time, the motivations of the parties involved in the collaborative tourism service, i.e. providers and customers, are different (Benoit et al., 2017). Investigating particular features of entrepreneurs in different sectors would be an important point to further policies to fostering entrepreneurship in the collaborative economy (Badulescu and Badulescu, 2014).

The collaborative economy could also benefit from turning to ecotourism, getting the conservation-oriented and community-based ecotourism to the mainstream through efficient marketing and reservation systems, and increasing customer acceptance of products with basic quality standards (Badulescu and Bac, 2009).

The emergence of COVID 19 is one of the most tragic changes in recent history. Shortly after the first case was identified, the way of life we had been used to has changed radically. Governments around the world have taken various decisions to prevent the global spread of COVID 19, such as travel bans for certain periods, containment measures, etc. The measures taken globally to prevent the spread of the disease have had an immediate impact on tourism activities. The World Tourism Organization has stated that the tourism industry is one of the hardest hit by the pandemic outbreak, with bilateral effects on both the supply and demand.

Airbnb has become one of today's leading platforms for travelers looking to book a unique place or tourist experience. Regardless of their motivation for accessing a collaborative tourism service, most studies have shown that the trend is growing and that people are increasingly open to such services. However, the COVID 19 pandemic has changed this trend, greatly reducing demand.

\section{Evolution of AIRBNB bookings in the first months of the COVID 19 pandemic}

The collaborative economy is not developed in the same way in all the areas in which it is present or the geographical areas it covers, although in Europe and the US this concept is well known. According to a study by Barnes and Mattson, global revenues from the collaborative economy are expected to grow to $\$ 335$ billion by 2025 (Barnes and Mattsson, 2016). 
Table 1. Monthly nights and experiences booked on Airbnb

2019

Oct Nov Dec Jan Feb Mar Apr May Jun Jul Aug Sep (in millions, except percentages)

\begin{tabular}{|c|c|c|c|c|c|c|c|c|c|c|c|c|}
\hline $\begin{array}{l}\text { Gross nights and } \\
\text { experiences booked }\end{array}$ & 30.5 & 28.3 & 28.4 & 38.3 & 32.8 & 19.0 & 8.7 & 16.4 & 26.0 & 28.3 & 26.0 & 23.9 \\
\hline \% Year-over-Year Change & $31 \%$ & $30 \%$ & $35 \%$ & $25 \%$ & $17 \%$ & $-42 \%$ & $-72 \%$ & $50 \%$ & 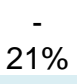 & $19 \%$ & $21 \%$ & $\begin{array}{c}- \\
23 \%\end{array}$ \\
\hline $\begin{array}{l}\text { Cancellations } \quad \text { and } \\
\text { alterations }\end{array}$ & 3.9 & 3.6 & 3.9 & 5.0 & 4.9 & 23.1 & 9.4 & 7.2 & 6.5 & 6.6 & 5.4 & 4.4 \\
\hline $\begin{array}{l}\text { Cancellations and } \\
\text { alterations as a \% of gross } \\
\text { nights and experiences } \\
\text { booked }\end{array}$ & $13 \%$ & $13 \%$ & $14 \%$ & $13 \%$ & $15 \%$ & $122 \%$ & $108 \%$ & $44 \%$ & $25 \%$ & $23 \%$ & $21 \%$ & $18 \%$ \\
\hline $\begin{array}{l}\text { Nights and Experiences } \\
\text { Booked (as net of } \\
\text { cancellations } \\
\text { alterations) }\end{array}$ & 26.6 & 24.7 & 24.5 & 33.3 & 27.9 & -4.1 & -0.7 & 9.2 & 19.5 & 21.7 & 20.6 & 19.5 \\
\hline$\%$ Year-over-Year Change & $31 \%$ & $30 \%$ & $35 \%$ & $22 \%$ & $12 \%$ & $114 \%$ & $103^{-}$ & - & $\begin{array}{c}- \\
31 \%\end{array}$ & - & $28 \%$ & - \\
\hline
\end{tabular}

While by the winter of 2020 all studies showed an increase in accommodation bookings via the Aibnb platform, with the emergence and global spread of the COVID 19 pandemic, this has taken an entirely different direction. This study aims to assess the extent to which the COVID 19 pandemic has reduced global bookings and therefore global revenue from this service.

It can be seen that bookings were significantly reduced in 2020 compared to 2019, therefore in April 2020 there was a 72\% decrease in bookings compared to the same period of the previous year. Although the COVID 19 pandemic made its presence felt in China in January 2020, Airbnb accommodation bookings did not decrease, but instead increased from 28.4 million in December 2019 to 38.3 million in January 2020, which means about 10 million more bookings. Even though in February 2020 the notion of COVID 19 was beginning to take shape at European level, tourists did not seem very worried about this, as evidenced by the fact that global bookings on Airbnb in February 2020 were 32.8 million. It is indeed a decrease compared to the previous month, but not a very dramatic one. It was only in March that bookings began to take a turn for the worse, dropping significantly to 19 million bookings on the platform. The direction to follow in the coming months is not encouraging, especially as April comes with the lowest value of bookings of only 8.7 million. Despite an upward trend in May compared to April, bookings are not very numerous (16.4 million). The period JuneAugust sees a slight increase and a stabilization of the number of bookings, due to better knowledge of the virus and the beginning of the holiday season but compared to 2019, it is still down by about $20 \%$. September again brings a slight decrease compared to August, which may also have been influenced by the forecast of wave 2 of the COVID 19 pandemic. It can also be seen that in the first two months of 2020, although the corona virus disease was known, Airbnb recorded increases of $25 \%$ in January and $17 \%$ in February, compared to the same months last year. This is largely due to the fact that people have not yet become aware of the severity of the situation. Therefore in March when the COVID 19 pandemic 
began to spread globally and claim numerous victims, bookings in the Airbnb system were down 42\% compared to March 2019, and in April 2020 the drop was even higher (72\%). During May-September the number of bookings decreased, but the decrease was relatively linear.

Regarding cancellations and alterations of services booked through Airbnb, we can say that they increased exponentially after the outbreak of the COVID 19 pandemic because people could no longer travel from one place to another and even if certain journeys were allowed, people were afraid or felt uncomfortable taking trips.

In January and February 2020 the number of cancellations and alterations increased compared to the previous months, while in March and April, as the COVID 19 pandemic intensified, the number of cancellations and alterations increased by $122 \%$ and $108 \%$ respectively, compared to the same period of the previous year. The following months maintain a high number of cancellations and changes, until September when it returns to a relatively normal level.

\section{The Airbnb's flexibility in the context of COVID 19}

In principle, the COVID 19 pandemic has significantly affected the collaborative accommodation sector, namely Airbnb, but the chances of a comeback are high, given the operating principle of Airbnb. Whereas in traditional accommodation, meeting other people is unavoidable, using Airbnb you can book your accommodation and buy it online and at your destination you'll have your own apartment or room waiting for you, without having to meet other people if you don't want to. In this respect, Airbnb accommodation could benefit in the context of this pandemic. In addition, COVID 19 has prompted hosts to adjust their offer to mitigate losses, to adopt safety measures for tourists, to shift their focus to domestic tourists rather than foreign ones as before, or to rent for longer periods of time.

Opinions on the Airbnb travel system in the context of COVID 19 are divided. Dolnicar and Zare, consider on the one hand that the pandemic is a super-shock (Dolnicar and Zare, 2020). Although shocks are nothing new for tourism, which is constantly subject to disruptive factors such as natural disasters, economic crises, etc., the pandemic has affected tourism in a different way. The reduction or even banning of travel is causing fundamental changes in the field of tourism. On the other hand they consider that the COVID 19 pandemic brings with it changes in the behaviour of collaborative accommodation providers, decreasing their flexibility and motivations to stay on platforms (Dolnicar and Zare, 2020). Therefore, the possibility of tourism as an economic sector, to reorganize and recover on relatively the same premises is seriously compromised, and even less the return to the situation of a real lifestyle of touristic operators (Badulescu and Badulescu, 2014).

Other researchers see Airbnb as a winner. Like the traditional tourism industry, online travel platforms have also faced the COVID 19 crisis. Airbnb has reacted promptly and managed this situation quite well considering that the regulatory framework is not very well defined in this area. Taulli says that Airbnb "has weathered the pandemic relatively well compared to other major travel operators, whether hotel chains or online marketplaces" (Taulli, 2020). On a different note, "the involvement of local authorities and private entities in identifying and exploiting Euroregion's touristic potential, in improving the quality and specificity of cross-border tourism product" (Badulescu, Badulescu and Borma, 2014).

\section{Conclusions}

The COVID 19 pandemic is certainly the most disruptive factor to tourism activities in recent history. This paper analysed the evolution of bookings, alterations and cancellations on Airbnb, the largest collaborative accommodation platform. Following the data presented above, it can be seen that the drop in the number of bookings was very large and was directly 
related to the events that happened since the beginning of the pandemic (the initial shock of blocking the Wuhan region), to the decisions that governments around the world took (blocking or even banning travel).As the table above shows, Airbnb booking cancellations have been numerous and managing and addressing them may be a new research topic.

At the same time, the COVID 19 pandemic has somewhat forced hosts to be more responsible when it comes to renting accommodation. There are many directions of research that can be explored that have been generated by the pandemic context. For example, one can look at the different elements of anxiety generated by the pandemic or how the Airbnb industry can survive and what opportunities it has in this period. As the effort to share property is not the same in different countries or cultures, this idea deserves further discussion in future studies, especially in the current global health context.

Most of the data shows that the consequences of the COVID 19 pandemic have had a strong negative impact on P2P rentals, in particular on the providers of such services, leaving them without customers and therefore without a significant part of their revenues.

Despite the fact that the research is brief, it provides some insight into how people have been booking since the outbreak of the pandemic and also provides a basis for more complex future research.

\section{References}

1. Bardhi, F., \& Eckhardt, G. (2012). Access-based consumption: The case of car sharing. Journal of Consumer Research, 39, 881-898.

2. Barnes, S.J. and Mattsson, J. (2016), "Understanding current and future issues in collaborative consumption: a four-stage Delphi study", Technological Forecasting and Social Change, Vol. 104, pp. 200-211.

3. Badulescu, A., Badulescu, D., (2014), Is There Evidence of a European Lifestyle Entrepreneur in Tourism? The Annals of the University of Oradea. Economic Sciences, 23(1), pp. 231-242.

4. Badulescu, A., \& Badulescu, D. (2014). IS THERE EVIDENCE OF A EUROPEAN LIFESTYLE ENTREPRENEUR IN TOURISM?. Annals of Faculty of Economics, 1(1), 231-242.

5. Badulescu, A., \& Badulescu, D. (2016). Entrepreneurship and Local Resources. Tourism Enterprises and the Sustainability Agenda across Europe, 169-186.

6. Badulescu, A., Bac. D. (2009), Profile of Ecotourists in Apuseni Mountains Natural Park. GeoJournal of Tourism and Geosites, 1, 7-16.

7. Badulescu, A., Badulescu, D., \& Borma, A. (2014). Enhancing cross-border cooperation through local actors' involvement. The case of tourism cooperation in Bihor (Romania)-Hajdú-Bihar (Hungary) Euroregion. Lex Localis-Journal of Local Self-Government, 12(3), 349-371.

8. Benoit, S., Baker, T.L., Bolton, R.N., Gruber, T. and Kandampully, J. (2017), "A triadic framework for collaborative consumption (CC): motives, activities and resources and capabilities of actors", Journal of Business Research, Vol. 79, pp. 219-227.

9. Caldieraro, F., Zhang, J.Z., Cunha, M., Jr. and Shulman, J.D. (2018), "Strategic information transmission in peer-to-Peer lending markets", Journal of Marketing, Vol. 82 No. 2, pp. 42-63.

10. Dolnicar, S. \& Zare, S., (2020). COVID19 and Airbnb - Disrupting the Disruptor. Annals of Tourism Research, 83, pp. 102961, https://doi.org/10.1016/j.annals.2020.102961.

11. Gretzel, U., Werthner, H., Koo, C., \& Lamsfus, C. (2015). Conceptual foundations for understanding smart tourism ecosystems. Computers in Human Behavior, 50, 558-563.

12. Juul, M. (2015). The sharing economy and tourism. European Parliament Research Service (EPRS), briefing. Retrieved from http://www.europarl.europa.eu/RegData/etudes/BRIE/2015/568345/EPRS BRI(2015)568345 EN.pdf

13. Statista (2021) Airbnb https://www.statista.com/, accessed 14.04.202.

14.Taulli, T., 2020. How Airbnb Beat The Covid-19 Virus. Available at: https://www.forbes.com/sites/tomtaulli/2020/11/21/how-airbnb-beat-the-covid-19virus/?sh=7f1574d2bcf2. 